\title{
The Effect of Claim Expense, Liquidity, Risk-Based Capital, Company Size, Debt to Equity, and Debt To Asset on Profitability In Indonesia Islamic Insurance Companies
}

\author{
Suryo Budi Santoso ${ }^{1}$, Herni Justiana Astuti ${ }^{2}$, Lulu Mardhiyah Sayekti ${ }^{3}$ \\ \{suryobs@gmail.com¹, herni99@gmail.com², lulumardhiyahsayekti@yahoo.co.id\} \\ Faculty of Economics and Business, Universitas Muhammadiyah Purwokerto
}

\begin{abstract}
The purpose of this study was the effect of claim expense, liquidity, riskbased capital, company size, debt to equity, and debt to an asset to profitability in Indonesia Islamic Insurance companies. The number of research samples is 70 consisting of general insurance companies in sharia business units that are registered with the Financial Services Authority in 2014-2018. This research was analyzed by multiple regression analysis. The research model fulfills the Goodness of Fit criteria, with the variability of the independent variable to the stock price of 40.0 percent. The results of the multiple linear regression test are size variable had a significant positive effect on Profitability, while the DER variable had a significant negative effect on Profitability. On the other hand, DAR, RBC, LQ, and CE variables on Profitability is not significant.
\end{abstract}

Keywords: Islamic Insurance, Claim Expense, Liquidity, risk Base Capital, size, Profitability

\section{Introduction}

Nowadays there are many risks. Starting from the risk of contracting Covid-19 or Corona disease, the risk of getting hit on the highway, and other risks. These risks make people feel less or uncomfortable. Discomfort in life can be reduced by sharing risk. The way to share risk in the modern era is with insurance. Insurance provides partial risk services from humans. Thus, humans can feel safe in their lives because there is already a guarantee if there are risks to themselves through insurance services [1].

Insurance companies must have good performance. One measurement of good performance is to look at profitability. Profitability is the ability of a business to obtain efficient income by utilizing the assets of the company. So, profitability is an important factor in financial management [2]. Profitability in the Islamic financial system is fully guaranteed by real economic growth, while profitability in the conventional financial system is not driven by the real sector[3].

Profitability is very important for insurance companies. The factors that affect profitability include claim expense, liquidity, risk-based capital, company size, debt to equity, and debt to asset. Previous research has not shown consistency in this problem so that it still creates research gaps. Such as company size on profitability by Pranata [4], [5]; Debt to equity ratio have a gap the result from previous researcher likes [6], [7]. [8]. 
Insurance companies raise funds from the public through insurance premium payments. Funds must be managed properly at the insurance company is very important. Because a good insurance premium fund affects the cost of claims that must be paid by insurance companies. Therefore, the burden of claims has a positive effect on the profitability of insurance companies [9]. Nurorsis and Rahayu find the opposite, namely Claims negatively affect profitability in life insurance companies in Indonesia [10]. This study is different from previous studies, especially with a total of 7 independent variables to 1 dependent variable. Research on profitability in Islamic insurance companies usually only examines 3 or 4 independent variables.

\section{Literature Review}

Pecking order theory is one of the capital structure theories discovered by Stewart C. Myers [11]. According to Myers [12], the Pecking order theory explains as follows: first, companies prefer internal finance. Second, the company tries to adjust the targeted dividend payout ratio with the investment opportunities that exist. Third, a fixed dividend policy, coupled with unpredictable profitability fluctuations and investment opportunities results in that cash flow generated internally may be more or less than the funds needed for investment. If less, the company will reduce the cash balance or portfolio of securities. Then finally, if external finance is needed, the company will issue the safest securities first. Starting from debt, then followed by securities that are characterized by options such as convertible bonds, and if still not sufficient, new shares are issued.

According to Fahmi [13], pecking order theories can be used as a policy pursued by companies to find additional funds needed. This can be done by selling the assets owned by the company, such as selling buildings, land, equipment, and other assets, including issuing and selling shares in the capital market and funds from retained earnings. The pecking order theory policy is expected that a company can minimize the risks that will arise with the right strategy. The strategy can be done by applying the principle of prudential (prudential principle) before making a decision based on a mature calculation.

\subsection{Claim expense}

The insurance claim is an official request to an insurance company to request payment based on the insurance policy. The proposed Insurance Claim will be reviewed by the company for its validity and then paid to the insured party after it is approved. According to article 246 of the Commercial Law, Insurance claims are claims by the insured in connection with the contract between the insurance company and the insured party. Each party commits itself to guarantee payment of compensation by the guarantor if payment of insurance premiums has been made by the insured party. When there is a disaster suffered by the insured party. The purpose of the insurance claim is to provide benefits under the provisions of the insurance policy to the policyholder (the insured) [14].

\subsection{Liquidity}

Liquidity is the company's ability to meet its obligations to pay short-term debts that must be paid immediately using current assets such as business debt, dividend debt, tax debt, and others. Simultaneously operating cash flow, investment cash flow, and funding cash flow 
influence company liquidity [15]. Simultaneously capital structure, firm size, and liquidity have a significant influence on the profitability of the manufacturing company's food and beverage sub-sector listed in Indonesia stock exchange [16].

\subsection{Risk-based capital}

Risk-based capital is the minimum solvency level of insurance and reinsurance companies that must be achieved with as much as possible [17]. Risk-based capital can also be interpreted as the financial health ratio of insurance companies by allocating existing funds to cover the risk of losses that will arise [18]. In Islamic insurance companies, risk-based capital consists of two types, namely risk-based capital from Tabarru funds and company funds. Tabarru funds' are funds used by participants to bear the risk of loss or funds used for payment of claims, reserves, and other costs such as Islamic reinsurance, while company funds are funds used for company operations [19].

\subsection{Debt to equity ratio}

The debt to equity ratio is one indicator of the measurement of the leverage ratio. According to Sugiono and Untung [20], leverage ratio aims to predict expenditures made by looking at the composition of debt and capital as well as the company's ability to pay other expenses. The debt to equity ratio shows the ratio of debt and capital of a company. This ratio is important because it relates to the problem of trading on equity which can have a positive or negative effect on the company's capital rentability.

\subsection{Debt to asset ratio}

This ratio is comparing the company's debt by looking at the ratio of total debt divided by total assets [13]. Generally, the leverage ratio discusses how much the company is financed with debt. However, the use of debt that is too high can endanger the company because the company will fall into the extreme leverage category. Extreme debt can occur when a company has a high level of debt but it is difficult to fulfill its debt obligations. Such conditions can be overcome if the company can balance how much debt must be taken to suit the needs. Then, companies must be clever in determining where sources can be used to pay off existing debt.One of the goals of Islamic insurance companies is a good profitability. Good profitability certainly hopes to get high income and reduce costs. One of them is by applying the pecking order theory as described above. Islamic insurance companies also need to pay attention to costs that can reduce profitability, including claim costs, risk-based capital. Other things that can increase profitability also need to be considered such as liquidity, company size, debt to equity, and debt to asset. There is great hope if an Islamic insurance company can pay attention to the above aspects, it is hoped that it can control costs and revenues in the future so that the level of profit or profitability can have good performance.

\section{Method}

\subsection{Population and Sample}

Not all elements or subjects to be studied can be observed correctly, this is due to limitations, therefore research needs to be drawn from the sample population. While the 
sample is part of the population to be tested its characteristics [21]. The population in this study is insurance companies. The sample of the population is a sharia unit insurance company that is officially registered under the Financial Services Authority in the year 2014-2018. The sample in this study used a purposive sample technique. The sample criteria in this study are:

a. Insurance companies, especially general insurance companies of sharia business units registered with the Financial Services Authority (OJK).

b. The company presents the complete sharia business unit financial statements, especially in 2014 - 2018.

c. There is information about accounts relating to claim an expense, liquidity, company size, debt to equity ratio, debt to asset ratio, risk-based capital, and profitability in the financial statements presented.

Data samples were processed as many as 55 samples.

\subsection{The Data Analysis}

a. Regression Analysis

The analytical method in this study uses multiple regression analysis. Therefore, the regression equation model is as follows:

$$
\mathrm{Y}=\alpha+\beta_{1} \mathrm{X}_{1}+\beta_{2} \mathrm{X}_{2}+\beta_{3} \mathrm{X}_{3}+\beta_{4} \mathrm{X}_{4}+\beta_{5} \mathrm{X}_{5}+\varepsilon
$$

Remarks:

$\mathrm{Y}=$ Profitability

$\alpha=$ intercept/Constanta

$\beta_{1}, \beta_{2}, \beta_{3}, \beta_{4}, \beta_{5}=$ partial regression coefficients of the dependent variable

$\mathrm{x}_{1}=\operatorname{Size}(\mathrm{Sz})$

$\mathrm{x}_{2}=$ Debt Equity Ratio (DER)

$\mathrm{x}_{3}=$ Debt Asset Ratio (DAR)

$\mathrm{x}_{4}=$ risk based capital $(\mathrm{RBC})$

$\mathrm{x}_{5}=$ Liquidity Ratio (LQ)

$\mathrm{x}_{6}=$ Claim Expense $(\mathrm{CE})$

$\mathrm{X}_{7}=$ Return on Asset (ROA)

$\varepsilon=$ error for the i-observation

b. Classic assumption test

The multiple linear regression model must meet the classical assumption test. This is useful to state that this model is good [22]. Some classic assumption testing tools are used [23]:

1) The normality test aims to test whether the regression model of the confounding or residual variables has a normal distribution.

2) Multicollinearity test aims to test whether in the regression model used there is a correlation between independent variables.

3) Heteroscedasticity test aims to test whether in the regression model variance from residual inequality occurs one observation to another observation.

4) Autocorrelation test aims to test whether in the linear regression model there is a correlation between the confounding errors in period $t$ with the interfering error in period t-1 (before). 
c. Goodness of Fit

1. Coefficient of Determination

This test aims to measure how far the model's ability to explain the variation of the dependent variable. The small value of $\mathrm{R}^{2}$ means that the ability of independent variables to explain the dependent variable is very limited. Conversely, if the value of $\mathrm{R}^{2}$ is close to one, it means that the independent variables provide almost all the information needed to predict the dependent variable.

2. Simultaneous Significance Test (F Test)

The F statistical test shows whether all the independent or free variables included in the model have a joint effect on the dependent variable. H0: $\mathrm{b} 1=\mathrm{b} 2=\ldots$ $=\mathrm{bk}=0$, meaning whether all independent variables are not significant explanations of the dependent variable. HA: $\mathrm{b} 1 \neq \mathrm{b} 2 \neq \ldots \neq \mathrm{bk} \neq 0$, meaning that all independent variables simultaneously are significant explanations of the dependent variable.

d. Significant Individual Parameter Test (t-Test)

The $t$ statistical test shows how far the influence of one independent variable / explanatory individually in explaining the variation of the dependent variable. H0: bi $=0$, meaning whether an independent variable is not a significant explanation of the dependent variable. HA: $b i \neq 0$, meaning that the variable is a significant explanation of the dependent variable

\section{Result And Discussion}

1) The result of the classic assumption test, One-Sample Kolmogorov-Smirnov Test Normality Test obtained the Sig. (2-tailed) of $0.06>0.05$. This means that standardized residual values are declared to spread normally.

2) Based of The results of the Tolerance value indicate that there is no independent variable that the value of Variance Inflation Factor (VIF) has a VIF value of more than 10, and a Tolerance value is less than 0.10 . It can be concluded that there is no multicollinearity between independent variables in the regression model.

3) The sum-up of the Heteroscedasticity test with the Glejser method it is known that the regression model does not occur symptoms of heteroscedasticity. This is because of the Sig. independent variables on residual absolute $>0.05$.

4) The last test of the classic test is the Autocorrelation test, and the results using the Durbin Watson method obtained a DW value of 2.073. Based on the location of the DW value is 2.073 located between $\mathrm{dU}$ and 4-dU, it can be said that the regression equation model does not contain autocorrelation problems.

Table 1. Determination Coefficient Results.

\begin{tabular}{|c|c|c|c|c|c|}
\hline \multicolumn{6}{|c|}{ Model Summary } \\
\hline Model & $\mathrm{R}$ & R Square & $\begin{array}{l}\text { Adjusted R } \\
\text { Square }\end{array}$ & $\begin{array}{l}\text { Std. Error of the } \\
\text { Estimate }\end{array}$ & $\begin{array}{l}\text { Durbin- } \\
\text { Watson }\end{array}$ \\
\hline 1 & $.683^{\mathrm{a}}$ & .467 & .400 & .03161 & 1.762 \\
\hline $\begin{array}{l}\text { a. Pred } \\
\text { b. Depe }\end{array}$ & $\begin{array}{l}\text { rs: (Co } \\
\text { ent Var }\end{array}$ & $\begin{array}{l}\text { istant), CE, I } \\
\text { able: ROA }\end{array}$ & $\mathrm{R}, \mathrm{RBC}, \mathrm{LQ}, \mathrm{Si}$ & e, DER & \\
\hline
\end{tabular}


Based on Table 1 we see the Adjusted R-Square value is 0.400 . This means that $40 \%$ of the Profitability variable can be explained by variations in the six independent variables, namely CE, DAR, RBC, LQ, Size, and DER. While the remaining $60 \%$ is explained by other reasons outside the model.

Table 2. F Test Results

\begin{tabular}{lrrrrr}
\hline \multicolumn{5}{c}{ ANOVA } \\
Sum of & & Mean & & \\
Model & Squares & df & Square & F & Sig. \\
\hline Regression & .042 & 6 & .007 & 7.002 & $.000^{\mathrm{b}}$ \\
Residual & .048 & 48 & .001 & & \\
Total & .090 & 54 & & & \\
a. Dependent Variable: ROA & & & & \\
b. Predictors: (Constant), BK, DAR, RBC, RL, UP, DER & & \\
\hline
\end{tabular}

Based on the ANOVA test results in Table 2, the calculated F value is 7.002 with a significance value of $<0.05$, then the regression model can be used to predict that CE, DAR, $\mathrm{RBC}, \mathrm{LQ}$, Size, and DER together influence profitability.

Table 3: The Results of t-Test

\begin{tabular}{lcccrc}
\hline \multicolumn{7}{c}{ Coefficients } \\
\multicolumn{7}{c}{ Standardized } \\
Model & Unstandardized Coefficients & Coefficients & & \\
(Constant) & $\mathrm{B}$ & Std. Error & Beta & $\mathrm{t}$ & \multicolumn{1}{c}{ Sig. } \\
Size & -.754 & .172 & & -4.387 & .000 \\
DER & .032 & .007 & .726 & 4.573 & .000 \\
DAR & -.099 & .022 & -1.437 & -4.571 & .000 \\
RBC & .209 & .077 & .873 & 2.698 & .010 \\
LQ & $-3.321 \mathrm{E}-5$ & .000 & -.226 & -1.691 & .097 \\
CE & $-1.455 \mathrm{E}-7$ & .000 & -.008 & -.057 & .955 \\
a. Dependent Variable: ROA & $4.473 \mathrm{E}-6$ & .000 & .019 & .165 & .870 \\
\hline \multicolumn{7}{c}{} \\
\hline
\end{tabular}

In Table 3, it can be seen that of the five independent variables, the Size and DER variables show a sig value of $<0.05$, it can be concluded that Size and DER variables have a significant effect on Profitability. While the significance of DAR, RBC, LQ, and CE variables are $>0.05$, it can be concluded that the effect of the DAR, RBC, LQ, and CE variables on the Profitability is not significant.

Based on the table above the multiple linear regression equation is made as follows $\mathrm{Y}=-754+0.032 \mathrm{X}_{1}-0,099 \mathrm{X}_{2}+0.209 \mathrm{X}_{3}-3.221 \mathrm{~W}-5 \mathrm{X}_{4}-1.455 \mathrm{E}-7 \mathrm{X}_{5}+4.473 \mathrm{E}-6 \mathrm{X}_{6}+\varepsilon$

a) The results of this study are specifically about Size variables. This study found that one variable had a significant positive effect on Profitability. This is in line with the findings from Wikardi dan Wiyani [5], and Pranata [4]. This also in line with agency theory, that the big size company can give a signal also big or good profitability.

b) On the other hand, the DER variable is opposide. This study found that DER had a significant negative effect. This is support by Wedyaningsih et al [24], Mahardika, and Marbun [7]. This is not in line with agency theory, that a good DER in a company can give a signal bad profitability. This is a new finding and it needs further research to make sure that DER is a negative effect on profitability. 
c) The results show that DAR, RBC, LQ, and CE variables on Profitability is not significant. Profitability must be maintained by the company because profitability is one of the ratios that will attract investors to work together or invest. In insurance companies, profitability can be influenced by risk-based capital (RBC) which is useful to minimize the risk of losses that will arise. This is contra with the result of this research. So, it is interesting to the next researcher. Insurance companies will increasingly be able to get a chance in high profits if the financial health of the insurance company is maintained and following regulations regarding the financial health of insurance companies that have been set by the government. Funding decisions are in line with the pecking order theory, this can be measured using debt to equity ratio and debt to asset ratio. A company that obtains additional funds from debt and equity capital itself can increase its assets so that operational activities run smoothly and also the achievement of profits can be obtained optimally. The result of this research is relevant to other researchers such as Agustina and Santosa [25], Sari and Asiah [26], Kusuma [27], Supriyono [28], Aprilino [29], Wani and Dar [30].

\section{Conclusions}

Tests using multiple linear regression analysis have resulted;

a. The size variable had a significant positive effect on Profitability.

b. DER variable had a significant negative effect on Profitability

c. DAR, RBC, LQ, and CE variables on Profitability is not significant.

A limitation of this study is the finding that the debt to equity ratio has a negative effect on profitability. This is contrary to the theory agency. So that further research is needed whether it is true that DER or owner's capital has a negative effect on profitability. Further research is also needed to add or look at other variables that can affect profitability, such as tabarru fund underwriting surplus, net investment income ratio, investment balance with liabilities ratio, tabarru fund change ratio, and others

The implication of the findings of this study is that an Islamic insurance company should make it a large Islamic insurance company. This is because a large Islamic insurance company can significantly affect the level of profitability.

\section{References}

[1] N. Nurlaelah And S. Falah, "The Effect Of Promotion Costs On Net Profit Margin In Subsectors Insurance Companies Listed In Indonesia Stock Exchange," Asia Pacific J. Manag. Stud., Vol. 4, No. 3, Pp. 225-248, 2012, Doi: 10.4135/9781452231334.N16.

[2] F. Agustin, A. Suangga, And B. Sugiharto, "Pengaruh Premium Growth Ratio, Risk Based Capital Dan Hasil Investasi Terhadap Profitabilitas Perusahaan Asuransi Umum Yang Terdaftar Di Bursa Efek Indonesia Tahun 2010-2014," Accruals (Accounting Res. J. Sutaatmadja), Vol. 2, No. 2, Pp. 53-65, 2018.

[3] S. B. Santoso, "Possibility Of Intensifying And Socializing The Islamic Banks In Indonesia : Supporting The Indonesian Financial System Stabilization And Searching For Social Significance In The Islamic Banks In Indonesia Suryo Budi Santoso Student Id No : 
1221072011 Gra," Dr. Disertation - Kanazawa Univ. - Japan, 2016.

[4] A. . W. D. Pranata, "Pengaruh Capital Adequacy Ratio, Loan To Deposit Ratio Dan Ukuran Perusahaan Pada Profitabilitas Bank Di Bursa Efek Indonesia.," E-Jurnal Akunt. Univ. Udayana, Vol. 11, No. 1, Pp. 235-251, 2015.

[5] L. D. Wikardi And N. T. Wiyani, "Pengaruh Debt To Equity Ratio, Firm Size, Inventory Turnover, Assets Turnover Dan Pertumbuhan Penjualan Terhadap Profitabilitas (Studi Kasus Pada Industri Makanan Dan Minuman Yang Terdaftar Di Bei Periode 2011-2015).," J. Online Insa. Akuntan., Vol. 2, No. 1, Pp. 99-118, 2015.

[6] A. Kridasusila And W. Rachmawati, "Determinan Struktur Modal Dalam Perspektif Pecking Order Theory Pada Perusahaan Sub Sektor Makanan Dan Minuman Yang Terdaftar Di Bei.," Bisma, Vol. 13, No. 1, Pp. 60-66, 2019.

[7] P. A. Mahardhika And D. Marbun, "Pengaruh Current Ratio Dan Debt To Equity Ratio Terhadap Return On Assets," Widyakala, Vol. 3, No. 1, Pp. 23-28, 2016.

[8] A. F. W. Efendi And Seto S. A. W, "Pengaruh Debt To Equity Ratio (Der) Dan Debt To Asset Ratio (Dar) Terhadap Kinerja Perusahaan Di Sektor Keuangan Yang Terdaftar Di Bursa Efek Indonesia," J. Appl. Manag. Account., Vol. 1, No. 2, Pp. 157-163, 2017.

[9] R. Trisnawati, "Analysis Of The Effect Of Claims And Underwriting Ratios On The Profitability Of Insurance Companies Listed On The Indonesia Stock Exchange.” Stie Ekuitas, 2015.

[10] D. S. Nurrosis And S. Rahayu, "Effects Of Risk Based Capital, Premium Growth And Claim Expenses On Profitability (Case Study Of Life Insurance Companies Registered At The 20132018 Financial Services Authority),"Vol. 7, No. 1, Pp. 982-989, 2020.

[11] S. Husnan, Manajemen Keuangan Teori Dan Penerapan (Keputusan Jangka Panjang). Yogyakarta: Bpfe Yogyakarta, 1996.

[12] S. C. Myers, "Capital Structure Puzzle,” National Bureau Of Economic Research, 1984.

[13] I. Fahmi, Financial Statement Analysis. Bandung: Alfabeta., 2011.

[14] S. Handayani, "Effect Of Insurance Claim Settlement Against Achievement Of The Sales Target Of Ajb Bumiputera 1912 Bengkulu Branch Insurance Products," Ekombis Rev. J. Ilm. Ekon. Dan Bisnis, Vol. 5, No. 1, Pp. 79-85, 2017.

[15] N. P. A. P. Dewi, L. K. Datrini, And L.G.P Sri Eka Jayanti, "The Influence Of Cash Flow On Company Liquidity In Manufacturing Companies That Go Public, Sub Sectors Consumption Goods Industry," Wicaksana, J. Environ. Dev., Vol. 4, No. 1, Pp. 59-62, 2020.

[16] S. Susiyanti And B. Effendi, "Capital Structure, Company Size, Liquidity And Profitability Of Manufacturing Companies Listing On The Idx," Own. (Research Account. Journal), Vol. 3, No. 2, Pp. 66-72, 2019.

[17] I. A. I. P. Sastri, E. Sujana, And N. K. Sinarwati, "Effects Of Premium Income, Underwriting Results, Investment Results And Risk Based Capital On Insurance Company Profit (Empirical Study Of Insurance Companies Listed On The Indonesia Stock Exchange For The Period 20112015).," Jimat (Jurnal Ilm. Mhs. Akunt., Vol. 7, No. 1, 2017.

[18] K. Handayani, “Analysis Of Financial Performance Of Bumn Go Public Insurance Companies (Using Ratio And Risk Based Capital Analysis).," J. Manag. Bus. Stud., 2015.

[19] A. N. Bayinah, S. M, S. M, And E. M, Sharia Insurance Accounting. Jakarta, Indonesia: Salemba Empat, 2019.

[20] A. Sugiono And E. Untung, Basic Practical Guide To Financial Statement Analysis. Jakarta, Indonesia: Pt Grasindo, 2016.

[21] Suliyanto, Business Research Method. Yogyakarta: Andi Offsett, 2018.

[22] Sujarweniv.W., Kupas Tuntas Penelitian Akuntansi Dengan Spss. Yogyakarta: Pustaka Baru Press, 2016.

[23] I. Ghozali, Multivariate Analysis Application With The Ibm Spss 23 Program. Semarang, Indonesia: Diponegoro University Publisher Agency, 2016.

[24] N. Wedyaningsih, S. N, And K. H. T., "Earning Per Share, Debt To Equity Ratio, Current Ratio Terhadap Profitabilitas Perusahaan Sub-Sektor Barang Konsumsi Di Bursa Efek Indonesia," J. Ilm. Edunomika, Vol. 3, No. 1, Pp. 97-107, 2019. 
[25] R. C. Agustina And A. Santosa, "Pengaruh Dar, Der Dan Tata Kelola Perusahaan Terhadap Kinerja Keuangan Perusahaan Farmasi,” J. Ekon. Dan Manajemen., Vol. 3, No. 1, Pp. 16-34, 2019.

[26] R. Y. R. Sari And A. N. Asiah, "Pengaruh Leverage Keuangan Terhadap Profitabilitas Pada Perusahaan Manufaktur Yang Terdaftar Di Bursa Efek Indonesia Periode 2010 - 2013, J. Manaj. Akunt., Vol. 16, No. 1, Pp. 67-76, 2016.

[27] R. P. Kusuma, "Pengaruh Dar, Ukuran Perusahaan, Risiko, Pajak, Dan Likuiditas Terhadap Profitabilitas Perusahaan Sektor Pertambangan Di Indonesia," Bisma (Bisnis Dan Manajemen), Vol. 8, No. 2, Pp. 191-203, 2016.

[28] A. E. Supriyono, "Pengaruh Risk Based Capital Terhadap Profitabilitas Pada Perusahaan Asuransi Syariah.," J. Akt. Ris. Akunt. Dan Keuangan., Vol. 1, No. 1, Pp. 28-39, 2019.

[29] A. D. Aprilino, “Analisis Pengaruh Solvabilitas Dan Underwritting Terhadap Profitabilitas Perusahaan Asuransi Kerugian (Studi Pada Perusahaan Asuransi Kerugian Yang Listing Di Bursa Efek Indonesia Tahun 2008-2012).," Artik. Ilm. Stie Perbanas Surabaya, 2014.

[30] A. A. Wani And S. A. Dar, "Relationship Between Financial Risk And Financial Performance: An Insight Of Indian Insurance Industry," Int. J. Sci. Res., Vol. 4, No. 11, Pp. 1424-1433, 2015. 